\title{
Phenomenology Study: Community Perception of Lush Disease In The Working Area of Puskesmas Talango, 2020
}

\author{
Mukhlish Hidayat ${ }^{1 *}$, Diana Irawati ${ }^{1}$, Agung Waluyo ${ }^{2}$ \\ ${ }^{1}$ Universitas Muhammadiyah Jakarta, Indonesia \\ ${ }^{2}$ Universitas Indonesia, Indonesia \\ *mukhlish0102@gmail.com
}

\begin{abstract}
Leprosy (Morbus Hansen) is a chronic infectious disease of the skin caused by Mycobacterium leprae, leprosy is also known as "the great imitator disease" because of the similar manifestations to other skin diseases such as fungal infections so that a person rarely realizes that he has had leprosy. This qualitative study was conducted to explore community perceptions about leprosy with 6 male and 4 female participants. The method used is a phenomenological approach with consecutive sampling as a sampling technique. There are 5 themes obtained in this study, namely factors that influence perception, the form of public perception of leprosy patients, community behavior in preventing leprosy transmission, hope for leprosy patients, and hope for health workers. Health education about leprosy is needed by the community to deepen their knowledge about leprosy and the attitude of the community towards people with leprosy.
\end{abstract}

Keywords: Leprosy, Society, Perception 


\section{STRADA Jurnal Ilmiah Kesehatan}

DOI: $10.30994 /$ sjik.v9i2.487

ISSN: 2252-3847 (print); 2614-350X (online)

Vol.9 No.2 November 2020 Page.1463-1473

\section{BACKGROUND}

Leprosy (Morbus Hansen) is a chronic infectious disease of the skin caused by Mycobacterium Leprae. The initial prediction of this disease is that the nerves and skin will then affect respiration and other organs, and do not affect the central nervous system. The discovery of leprosy cases in the world is still relatively high, in 2014 the World Health Organization (WHO) obtained data on leprosy cases totaling 213,899 cases of leprosy as the latest case finding of leprosy worldwide with the highest cases in the Southeast Asia region, amounting to 154,834 patients. Indonesia ranks third with 16,856 new cases after India and Brazil in the list of countries with the number of new cases (WHO 2014). In 2017, the prevalence of leprosy in Indonesia was 0.70 cases / 10,000 population and the number of new case findings was 6.08 cases per 100,000 population (Kemenkes RI, 2018). The highest number of sufferers is in East Java Province, with 3,373 new cases of leprosy in 2015-2017 (Kemenkes RI, 2018). East Java Province occupies the first position at the national level in cases of leprosy in 2018 with the largest contributor being Sumenep Regency which is spread over 30 working areas of (Dinas Kesehatan Propinsi JawaTimur, 2017). The prevalence of new leprosy discoveries in Sumenep Regency was 463 patients with the criteria for Pause Basiler (PB) leprosy with a total of 107 patients and Multi Basiler (MB) leprosy with a total of 356 cases in 2017 (Dinas Kesehatan Propinsi JawaTimur, 2017). Talango District is the district with the highest number of 47 new cases of leprosy in the Sumenep Regency (Local Health Office of Sumenep Regency, 2017). The high rate of leprosy is the impact of several factors that underlie the development of leprosy itself.

Several factors trigger leprosy in Indonesia, namely lack of knowledge, low sanitation, type of work, and socio-economic conditions. Environmental factors also have a big influence on the transmission of leprosy such as the density of the occupancy, the area of ventilation, especially access to clean water, which makes it easier for germs to develop and increase (Patmawati \& Setiani, 2015). The process of transmission of leprosy germs can be through the air, poor ventilation of the room can facilitate the development of more germs (Patmawati \& Setiani, 2015). The results showed that the cleanliness of the home environment includes cleanliness of the yard, personal hygiene of the people, and cleanliness of the house in the neighborhood, there are $33.9 \%$ of respondents who are not at risk in the control group, while there are $35.5 \%$ of respondents who have a clean environment at risk of leprosy. The results showed that there was a significant relationship between environmental hygiene and the incidence of leprosy with a p-value $=0.002<0.05$ 05 ( Sapriadi S, Risman Wanci, Syahridha, 2019). This behavior still occurs frequently, it is due to the low behavior of clean and healthy living (PHBS) in the community.

The results of interviews with the person in charge of leprosy at the Talango Health Center obtained information that the high number of new cases of leprosy was found due to the lack of knowledge and the low level of community PHBS. This is in line with the data from Talango District which was found in 2017, namely as many as $22.1 \%$ of the total 38,108 people who have low (Local Health Office of Sumenep Regency, 2017). When a person has been diagnosed with leprosy, many impacts arise on people with leprosy, both physically and psychologically, causing stress both emotionally, socially, and spiritually. The physical impact on individuals diagnosed with leprosy is the disability, the resulting disability makes individuals experience a lot of negative treatment from their environment (Lusli et al., 2015). Disabilities that appear suddenly, not at birth or during the early stages of development will have a negative psychological impact on each sufferer (Hendriani, 2016). 


\section{STRADA Jurnal Ilmiah Kesehatan}

DOI: $10.30994 /$ sjik.v9i2.487

ISSN: 2252-3847 (print); 2614-350X (online)

Vol.9 No.2 November 2020 Page.1463-1473

The most influential impact is the acceptance and support of relatives as well as closest friends and the community towards lepers, the large social impact on lepers, which causes very high anxiety and anxiety, not only for lepers themselves but also in their family, community, and state(Sodik, 2016). This is a form of signs and prejudice against leprosy which can have an impact on the psychology of leprosy patients who are the driving force for recovery (Grzybowski, Sak, Pawlikowski, \& Nita, 2016). On the other hand, the discrimination that occurs in the community as well as by relatives and closest friends of leprosy sufferers is caused by the fear of being infected as a trigger factor for stress in leprosy sufferers (Nasrudin, Yusuf, Hargono, \& Suwandi, 2018). The public perception that arises about leprosy is a frightening disease that is feared by not only the surrounding community but also their own families so that patients feel isolated when they gather together with their families and communities. Even people in the environment feel disgusted and afraid of leprosy sufferers and perceive leprosy as a disease that is difficult to treat, severe disease, and punishment by God (Kaehler, Adhikar, Raut, Marahatta, \& Chapman, 2015).

People stay away from leprosy sufferers due to a lack of knowledge and misunderstanding of the community about leprosy, some people still think that leprosy is a witchcraft disease or witchcraft that causes sufferers to be excluded from the environment even though this stigma occurs due to wrong perceptions in people's lives, especially rural communities (Istiarti \& Widagdo, 2009). This is in line with sulida's research in 2016 which states that public knowledge about leprosy is mostly still low due to the community's ignorance of leprosy itself and the negative attitude of society towards people with leprosy with a tendency towards discriminatory behavior by the community such as insulting speech to the form of expulsion of lepers. Based on this description, the authors are interested in conducting qualitative research on How the Community Perceptions of Leprosy in the Talango Community Health Center to identify in-depth information about people's perceptions of leprosy in the work area of the Talango Community Health Center 2020.

\section{METHODS}

The research design used in this study is a qualitative approach. The approach in this study uses a phenomenological approach. The participants in this study were 10 people who live around the house of people with leprosy with a maximum distance of $150 \mathrm{M}$. The participants were selected using the Consecutive sampling method which was then conducted in-depth interviews at face-to-face with the inclusion criteria of the participants being able to communicate, willing to be interviewed, living around lepers and make direct contact with lepers. In the data collection process, the main instrument in this study was the researcher, with the help of other instruments, namely field notes, interview guides, and recording devices. The study has passed the ethical review number 0460 / F.9-UMJ / IV / 2020.

This research was started in June-July and carried out the following stages of implementation: 1) In the implementation phase of the research, it was started after the participants signed a letter of consent to do the research and were willing to become participants and then the time contract researcher to conduct the interview The researcher began to arrange the place, explaining the contract agreed with the participants and asked about their readiness to conduct an interview, the researcher re-explained the research objectives and the protection of the confidentiality of participant's identity and data. 2) The researcher provides a comfortable atmosphere by adjusting the place of the interview 


\section{STRADA Jurnal Ilmiah Kesehatan}

DOI: $10.30994 /$ sjik.v9i2.487

ISSN: 2252-3847 (print); 2614-350X (online)

Vol.9 No.2 November 2020 Page.1463-1473

according to the wishes of the participants then the researcher prepares a field note format and turns on the Sony Voice Recorder to initiate communication between the researcher and the participants, while the agreed time is one meeting for $\pm 45-60$ minutes. 3) The researcher begins the interview by asking questions according to the interview guide that has been made by the researcher. Researchers asked open-ended questions to participants to obtain information about participant perceptions specifically and in detail. 4) During the interview the researcher observes the attitudes and behavior and conditions of the room which will be documented in field notes to complement the results of the interview. 5) Field notes during the interview process are used to document incidents such as facial expressions, non-verbal responses, atmosphere, and behavior of participants. 6) Furthermore, the researcher agreed to a contract at the next meeting, to validate the results of the interview data at the first meeting. If the data needed by the researcher is sufficient, the meeting will end. 7) The results of the interview will be confirmed to the participants in the verbatim form to see whether the participants agree with the results of the interview conducted by the researcher. 8) Furthermore, the researcher will consult with the supervisor with verbatim results to see the suitability and saturation of the data, as well as the participants who will be interviewed next. 9) The termination stage is carried out when the data from the participants is sufficient. Researchers will terminate in the form of gratitude and giving souvenirs to participants. Data analysis was carried out using the method popularized by John Creswell with the following stages: 1) preparing the data, 2) organizing the data, 3) reducing the data, 4) making a summary, and presenting the data.

\section{RESULTS}

\section{Respondent Characteristics}

Characteristics of the participants included gender, education level, occupation, distance of residence, marital status, ethnicity, and religion.

Table 1.Characteristics of Phenomenology Study Participants: Public Perceptions of Leprosy in the Talango Community Health Center Work Area in 2020

\begin{tabular}{|c|c|c|c|c|c|c|}
\hline $\begin{array}{l}\text { Partisi Gender } \\
\text { pant }\end{array}$ & Age $\quad$ Education Level & Profession & Distance & $\begin{array}{l}\text { Marital } \\
\text { Status }\end{array}$ & $\begin{array}{l}\text { Ethnic } \\
\text { Group }\end{array}$ & Religion \\
\hline
\end{tabular}

\begin{tabular}{lllllllll}
\hline P1 & M & 29 & Senior High School & Farmer & $\pm 150 \mathrm{~m}$ & Single & Madurese & Islam \\
\hline P2 & M & 30 & Senior High School & Farmer & $\pm 15 \mathrm{~m}$ & Married & Madurese & Islam \\
\hline P3 & F & 39 & College & Teacher & $\pm 50 \mathrm{~m}$ & Married & Madurese & Islam \\
\hline P4 & F & 32 & Senior High School & IRT & $\pm 15 \mathrm{~m}$ & Married & Madurese & Islam \\
\hline P5 & M & 32 & Senior High School & Teacher & $\pm 50 \mathrm{~m}$ & Married & Madurese & Islam \\
\hline P6 & F & 30 & Senior High School & Farmer & $\pm 35 \mathrm{~m}$ & Married & Madurese & Islam \\
\hline P7 & M & 53 & Junior High School & Farmer & $\pm 100 \mathrm{~m}$ & Married & Madurese & Islam \\
\hline P8 & M & 31 & Senior High School & Seller & $\pm 20 \mathrm{~m}$ & Married & Madurese & Islam \\
\hline P9 & M & 49 & Senior High School & Farmer & $\pm 50 \mathrm{~m}$ & Married & Madurese & Islam \\
\hline P10 & F & 41 & College & Teacher & $\pm 35 \mathrm{~m}$ & Married & Madurese & Islam \\
\hline
\end{tabular}

Based on the table above, the age of the participants at the time of the interview showed that the majority of participants were in the age range 29-32 years, as many as 6 participants. The gender distribution of the participants was dominated by men as many as 6 people with the majority of the work of the participants were farmers as many as 5 people. The education level of the majority of participants is high school graduates/equivalent, namely 7 participants. Overall the participants are people with the Madurese tribe. This study resulted in 5 themes, namely: factors that influence perceptions, 


\section{STRADA Jurnal Ilmiah Kesehatan}

DOI: $10.30994 /$ sjik.v9i2.487

ISSN: 2252-3847 (print); 2614-350X (online)

Vol.9 No.2 November 2020 Page.1463-1473

the form of public perception of leprosy patients, community behavior in preventing leprosy transmission, expectations for leprosy patients, and expectations for health workers. Each theme will be described one by one.

\section{Factors Affecting Perception}

Participants reveal the factors that influence perception through their experience and knowledge, the researcher identifies participants' knowledge about leprosy so that leprosy is identified, namely, skin diseases, inherited diseases, curses, and infectious diseases (P1, P2, P3, P4, P5, P6, P7, P8, P9, P10). Participants also said the signs and symptoms of leprosy were changes in skin appearance, weight loss, and disability (P1, P2, P3, P4, P5, P6, P7, P8, P9, P10). While the transmission of leprosy is human to human, through media and derivatives (P1, P2, P3, P4, P5, P6, P7, P8, P9, P10).

\section{Forms Of Public Perception Of Leprosy Patients}

The form of participants' perceptions of leprosy sufferers is caused by incorrect knowledge of participants so that the perceptions shown are feelings of disgust, fear, and worry (P1, P2, P3, P4, P5, P6, P7, P8).

\section{Community Behavior In Preventing Leprosy Transmission}

Participants' way of preventing the transmission of leprosy is by doing positive activities such as washing their hands after interacting with people with leprosy (P2, P3). In addition to positive activities, participants also do negative activities such as maintaining distance and rarely communicating $((\mathrm{P} 1, \mathrm{P} 2, \mathrm{P} 3, \mathrm{P} 5, \mathrm{P} 7, \mathrm{P} 9, \mathrm{P} 10)$ and doing activities that are detrimental to leprosy sufferers such as expulsion (P1, P2, P3, P7).

\section{The Expectations Of The Community For Leprosy Patients}

Participants have hopes for leprosy sufferers, where this hope is the participant's desire so that people with leprosy can change their health status such as getting well soon, following regular treatment, and maintaining cleanliness (P1, P2, P3, P4, P6, P7, P8, P9, P10) as well as in interacting with the community and being able to accept themselves (P4, P6). As well as increasing their spiritual activities (P2, P3).

\section{Expectations Of The Community For Health Personnel}

In addition to expectations for leprosy sufferers, participants also expressed hope for health workers, namely regular monitoring and better handling (P2, P3, P4, P6, P7, P9, P10), as well as providing health information in the form of counseling (P3, P5, P7 ).

\section{DISCUSSION}

\section{Factors affecting perception}

Public knowledge about leprosy shows that people consider leprosy to be a hereditary skin disease, contagious disease, and a cursed disease. This is supported by the results of the research (Earnest Njih Tabah et.al 2018) where the results of the research concluded that around $82 \%$ of respondents had heard of, and $64.4 \%$ knew someone with leprosy. Information on leprosy mostly comes from community volunteers (40.6\%), friends $(38.0 \%)$, and the media (24\%). The cause of leprosy was only $19.7 \%$ of respondents and quite a lot attributed it to spells (25.3\%), unclean blood (15.5\%), and heredity (14.6\%). About $72 \%$ know that leprosy can be cured and $86.3 \%$ recommend medical treatment. In the study (Anna T et.al 2019), there were 446 participants involved in this study: 100 


\section{STRADA Jurnal Ilmiah Kesehatan}

DOI: $10.30994 /$ sjik.v9i2.487

ISSN: 2252-3847 (print); 2614-350X (online)

Vol.9 No.2 November 2020 Page.1463-1473

people affected by leprosy, 111 close contacts, 185 community members, and 50 health workers. Also, 24 in-depth interviews were conducted and 35 people were involved in focus group discussions. $12.5 \%$ of participants have adequate knowledge about leprosy, while $22 \%$ have poor knowledge. Knowledge of causes (answered correctly by $10 \%$ of participants), mode of transmission (5\%), and symptoms of leprosy (16\%) was very poor. This means that the EMIC-CSS score was 15.3 (95\% CI 14.6-16.0) and the mean SDS score was 7.2 (95\% CI 6.6-7.8). Better knowledge about leprosy is associated with lower levels of social distancing with people affected by leprosy.

Muta'afi's research (2015) also shows that the community considers leprosy to be a skin disease, infectious disease, hereditary disease, and curse disease. The objectivation of society views a leper as a person affected by a curse. 2. The objectivation of the community that views lepers as sufferers of hereditary diseases. 3. The objectivation of the community that views lepers as sufferers of dangerous infectious diseases. 4. The objectivation of the community views lepers as sufferers of infectious diseases that can be cured.

Factors that influence the formation of people's perceptions of knowledge are identified from the experience of contact with leprosy patients which shows that people are trying to behave as usual. People still think that former leprosy sufferers still have leprosy and this bad stigma is based on the understanding of most people that leprosy is a cursed disease from God that can never be cured (Lesmana, 2014) Currently, India is home to about half of the leprosy patients in the world. Therefore it is very important for people to know about this disease and have a good attitude towards those suffering from this disease This study aims to assess the knowledge and attitudes of the general public about leprosy. A cross-sectional study was conducted among 384 study participants belonging to the rural field practice area of Govt Medical College and Hospital, Chandigarh. Trained workers obtain the information they want using a structured pre-designed questionnaire. Analyzes were performed using Epi-info software for windows. The findings indicated that half of the study participants had heard of leprosy (193/384; 50.3\%). Of them, 17.1\% (33/193) i.e. $33 / 384$ (8.5\% of the total study participants) knew that leprosy was caused by an infectious agent. About half $(58.5 \%)$ of participants with knowledge of leprosy were aware that skin patches were a sign of disease. There is an attitude of stigmatization; where only about a third of study participants were willing to shake hands (33.7\%) and sit with leprosy patients (33.2\%) (D Sharma, NK Goel, MK Sharma, MM Thakare, M Sharma, M Kaur, PD Pant. 2020).

\section{Forms of public perception of leprosy patients}

In this study, there is a form of public perception of people with leprosy, namely disgust, anxiety, and fear. The form of public perception of people with leprosy shows that people feel disgusted when they see the disability. This is in line with the results of the research (Isnandi \& Made 2020) which shows the information from the informants since the beginning of the existence of former lepers living in Sumberglagah Hamlet, the community does not appreciate and respect the former lepers, they keep their distance and often feel disgusted when they are close to former lepers. . Research (Jufrizal and Nurhasanah 2019) also shows that most people feel disgusted which is the source of the life problems of lepers, namely disability in the patient's body, causing negative social impacts from leprosy sufferers, namely the sufferers are shunned, ostracized by society and the emergence of acts of discrimination and sufferers find it difficult to get a profession. 


\section{STRADA Jurnal Ilmiah Kesehatan}

DOI: $10.30994 /$ sjik.v9i2.487

ISSN: 2252-3847 (print); 2614-350X (online)

Vol.9 No.2 November 2020 Page.1463-1473

In this study, there is also a form of public perception of people with leprosy which shows that people are anxious and afraid of contracting it. The attitude of tolerance possessed by the people of Sumberglagah Hamlet is certainly not easy to be applied by other communities because in practice many other communities ignore religious values, human values, and unity and also the value of harmony because many other people are disgusted and afraid of contracting leprosy (Isnandi \& Made 2020). The impact that arises on society is feeling disgusted by leprosy sufferers, staying away from people with leprosy and their families, and feeling annoyed by the presence of lepers (Kaur \& Van Brakel, 2002). The community thinks that leprosy is a dangerous contagious disease, a hereditary disease, a curse, so that people feel disgusted and afraid of leprosy sufferers, especially those with disabilities (Ministry of Health, 2006)

\section{Community Behavior In Preventing Leprosy Transmission}

The form of public attitudes towards sufferers of the disease is identified from the positive effect showing that the community adheres to health protocols after interacting with leprosy patients. The results of the study (Earnest Njih Tabah 2018) support the results of this study where attitudes towards lepers are generally negative. Only $42 \%$ will shake hands, $32.6 \%$ will share the same plate, and $28.3 \%$ and $27 \%$ will respectively allow their children to play or marry a leper. Furthermore, only $33.9 \%$ agree to the participation of lepers, and $42.9 \%$ work.

In this study, the form of public attitudes towards disease sufferers was identified from the negative effects showing that people maintain distance, reduce social contact, and stigma, namely in the form of discrimination and labeling. The impact of leprosy will have an impact on leprosy sufferers and their families. In the short term, the transmission of leprosy to their families is very vulnerable when in one house, one of which is to avoid transmission, one of which is to avoid direct contact with leprosy sufferers, this can prevent transmission of leprosy in the short term (Entjang, 2010). In the long term, leprosy transmission with household contact if not treated will contract leprosy if leprosy sufferers for a long time. Apart from being ostracized by the community, many families keep a distance from interacting with leprosy sufferers (Shielda 2018). Independent predictors of negative attitudes are the belief that leprosy is a curse; is caused by germs, and have seen patients with leprosy. The negative attitude is based on the belief that leprosy is a punishment, hereditary, and caused by poor personal hygiene research (Earnest Njih Tabah 2018).

The stigma of society has a huge impact on the lives of leprosy patients both mentally and psychologically because the sufferers feel isolated and even rejected and alienated by society. Most of the leprosy sufferers feel ashamed to socialize and mingle with the surrounding community because of the disability caused by the complications of leprosy. Leprosy sufferers mostly stay silent and hide in their respective homes because of the discriminatory treatment they receive from the community. Staying silent at home makes them not get the maximum treatment so that their condition gets worse until they become permanently disabled. This condition makes the process of leprosy transmission faster so that the prevalence of leprosy is increasing every year (Syahrul, 2019). The perception that exists in the community says that leprosy is a disease caused by the curse of God (Karma), which is hereditary and dangerous. (Tarigan, 2013). Even in India, people with leprosy are still considered as people who have grave sins and defame mankind so that people with leprosy often get bad treatment so that the community marks the leprosy sufferer by 


\section{STRADA Jurnal Ilmiah Kesehatan}

DOI: $10.30994 /$ sjik.v9i2.487

ISSN: 2252-3847 (print); 2614-350X (online)

Vol.9 No.2 November 2020 Page.1463-1473

obliging him to carry a bell if a family is suffering from leprosy and mark the residence (house) with another sign (Tony, 2017).

\section{The Expectations Of The Community For Leprosy Patients}

In this study, there is a form of public expectation for people with leprosy, namely in the form of improving health status, following health worker instructions, medication adherence, attitudes of leprosy patients, lifestyle, and spiritual activities. This is in line with the results of the research (Nur 2014). The hope of getting well from leprosy is an encouragement for them to immediately return to their life activities as before. Living normally in carrying out their roles and responsibilities is a matter of pride for them as proof of their existence in their daily lives. The results of the study (Meru et al. 2017) said that to achieve a cure for leprosy, regular treatment or compliance is required for each patient. The problem in leprosy treatment is the economic condition of the community and definite evidence shows that treatment adherence is still low.

Spiritual activity is a medium of individual communication with God. Individuals pray as a form of effort in obtaining healing. Spiritual activities are carried out individually and together to gain peace, such as accepting gracefully any unexpected conditions, including disability due to leprosy. Spirituality can overcome stress by suppressing negative responses to stressors (Debnam, Milam, Furr-Holden, \& Bradshaw, 2016). A good spiritual level in people with leprosy can reduce stress indicators such as emotional changes, behavioral and physical changes (Yadav, Khanna, \& Singh, 2017). Because spirituality teaches individuals to be broad-hearted, steadfast, calm in facing problems (A. Yusuf, Iswari, Nihayati, \& Okviasanti, 2016).

\section{Hope For Health Workers}

In this study, there is a form of public expectation for health workers, namely in the form of optimal service and health education. The existence of support from health professionals can affect compliance behavior, their support, especially in healthy living behavior. They also influence patient behavior by conveying their enthusiasm for certain actions from patients, and continuously by giving positive rewards for patients who have been able to adapt to their treatment and care programs. Meru et al (2017).

So that in this stage their status has changed from fellow patients to fellow relatives. The closeness is not only limited to fellow patients, doctors and nurses also develop closeness with patients in the hospital. This positive flow of objectification energy ultimately encourages them to externalize themselves in the hospital environment (Nur 2014). The results of this study are in line with the research of Meru et al. health workers and people affected by leprosy will affect adherence, for example, information with good supervision, the satisfaction of aspects of emotional relationships, and satisfaction with the treatment given. The frequency of supervision, support, or follow-up action is also quite important to note. Health education, rehabilitation, public contact, and rights-based counseling interventions, and community involvement can provide a common platform for community members and lepers to take the lead in providing community-based health education in addition to increasing social participation and interaction (Sujan et al 2018)

\section{CONCLUSIONS}

Public knowledge about leprosy is identified because of the perception of public knowledge about leprosy, namely knowledge about leprosy and experience of contact with leprosy patients 


\section{STRADA Jurnal Ilmiah Kesehatan}

DOI: $10.30994 /$ siik.v9i2.487

ISSN: 2252-3847 (print); 2614-350X (online)

Vol.9 No.2 November 2020 Page.1463-1473

Public perception of leprosy sufferers is in the form of feeling disgusted, anxious, and afraid of contracting them.

The attitude of the community towards leprosy sufferers is shown by the behavior of the community in preventing leprosy transmission in the form of positive effects, namely complying with health protocols, and negative effects, namely in the form of barriers to social interaction and public stigma.

The community's expectation for leprosy sufferers is to improve the health status of leprosy sufferers, attitudes, and spiritual activities, while the community's expectations for health workers are optimal service and health education.

\section{REFERENCE}

Afiyanti, Rachmawati, (2014). Metode Penelitian Kualitatif Dalam Riset Keperawatan. Jakarata : PT Raja Grafindo Persada.

Anna T. van 't Noordende, Ida J. Korfage, Suchitra Lisam, Mohammed A. Arif, Anil Kumar, Wim H. van Brakel 2019 The role of perceptions and knowledge of leprosy in the elimination of leprosy: A baseline study in Fatehpur district, northern India. PLOS Neglected Tropical Diseases

Aulia. (2019). Stigma Terhadap Penderita Kusta (Studi Tentang Bentuk Stigma dan Reaksi Terhadap Stigma yang Dialami Penderita Kusta dalam Proses Pengobatan di Kabupaten Mojokerto). IR-Perpustakaan Universitas Airlangga Stigma. Debnam, K., Milam, A. J., Furr-Holden, C. D., \& Bradshaw, C. (2016). The Role of Stress and Spirituality in Adolescent Substance Use. Substance Use and Misuse, 51(6), 733-741. https://doi.org/10.3109/10826084.2016.1155224

Dinas Kesehatan Kabupaten Sumenep. (2017). Profil Kesehatan Kabupaten Sumenep Tahun 2017.

Dinas Kesehatan Provinsi Jawa Timur. (2018). Profil Kesehatan Provinsi Jawa Timur Tahun 2017.

Entjang, I. (2010). Ilmu Kesehatan Masyarakat. Bandung : Citra Aditya Bakti

Elliya, R., Wahyuni, D., \& Hilmiah. (2019). Pendidikan Kesehatan: Tentang Kusta Dan Stigmatisasi Masyarakat Pada Penderita Kusta Di Kelurahan Sukadanaham Bandar Lampung. 13(1), 56-61.

Earnest Njih Tabah, Dickson Shey Nsagha, Anne-CeÂcile Zoung-Kanyi Bissek,Theophilus Ngeh Njamnshi, Irine Ngani-Nformi Njih, Gerd Pluschke, Alfred Kongnyu Njamnshi (2018) Community knowledge, perceptions and attitudes regarding leprosy in rural Cameroon: The case of Ekondotiti andMbonge health districts in the South-west Region. PLOS Neglected Tropical Diseases

Garamina, H. J. (2015). Hubungan Pengetahuan dan Sikap Masyarakat Terhadap Stigma Penyakit.

Grzybowski, A., Sak, J., Pawlikowski, J., \& Nita, M. (2016). Leprosy: Social implications from antiquity to the present. Clinics in Dermatology, 34(1), 8-10.

Govindharaj, P., Srinivasan, S., \& Darlong, J. (2018). Quality of Life of People Affected with Leprosy Disability Living in Purulia , International Journal of Health Sciences and Research Quality of Life of People Affected with Leprosy Disability Living in. 8(February), 221-225.

Govindharaj, P., Srinivasan, S., Darlong, J., Mahato, B., \& Acharya, P. (2018). A new instrument to measure leprosy internalised stigma: The leprosy internalised stigma scale (LISS). Leprosy Review, 89(3), 242-255.

Hidayati, F. \& A. (2019). Relationship Of Actual Stigma Leprosy With The Quality Of 


\section{STRADA Jurnal Ilmiah Kesehatan}

DOI: $10.30994 /$ siik.v9i2.487

ISSN: 2252-3847 (print); 2614-350X (online)

Vol.9 No.2 November 2020 Page.1463-1473

Life Of Leprosy Patients. Jurnal Kesehatan Al-Irsyad Vol XII, No. 1. Retrieved from : https://doi.org/10.1016/j.clindermatol.2015.10.009.

Hendriani, W. (2016). Pengembangan Modul Intervensi untuk Meningkatkan Resiliensi pada Individu yang Mengalami Perubahan Fisik Menjadi Penyandang Disabilitas. INSAN Jurnal Psikologi Dan Kesehatan Mental, 1(1), 66. Retrieved from : https://doi.org/10.20473/ipkm. v1i12016.66-75.

Isnanda Heni Arianti \& I Made Suwanda. (2020). Sikap Toleransi Masyarakat Terhadap Mantan Penderita Kusta Di Dusun Sumberglagah Desa Tanjung kenongo Mojokerto. Kajian Moral dan Kewarganegaraan. Volume 08 Nomor 02 , 641-655

Jufrizal, Nurhasanah. (2019). Stigma Masyarakat Pada Penderita Kusta. Vol. X No. 1

Kaehler N, Adhikar B, Raut S, Marahatta Sb, Chapman Rs (2015) Perceived Stigma Towards Leprosy Among Community Members Living Close To Nonsomboon Leprosy Colony In Thailand. Plos One 10(6): E0129086. Doi:10.1371/Journal. Pone.0129086

Lesmana, A. C. (2014). Hubungan Derajat Pengetahuan Masyarakat Tentang Penyakit Kusta Terhadap Penerimaan Sosial Pada Mantan Penderita Penyakit Kusta.

Local Health Office of Sumenep Regency. (2017). Profil Kesehatan Kabupaten Sumenep Tahun 2017. Retrieved from : http://sumenepkab.go.id/ berita/baca/menristekdiktiri-ist-annuqayah-untuk-penguasaan-sains-dan-teknologi-bagi-santri.

Lusli, M., Zweekhorst, M. B. M., Miranda-Galarza, B., Peters, R. M. H., Cummings, S., Seda, F. S. S. E., ... Irwanto. (2015). Dealing with stigma: Experiences of persons affected by disabilities and leprosy. BioMed Research International, 2015. Retrieved from : https://doi.org/10. 1155/2015/261329.

Muta'afi. (2015). Konstruksi Sosial Masyarakat Terhadap Penderita. Paradigma. Volume 03 Nomor 03 Tahun 2015

Nardi Assis, B. P., Lyon, S., De Faria Grossi, M. A., \& Da Costa Rocha, M. O. (2019). Risk factors for physical disability upon release from multidrug therapy in new cases of leprosy at a referral center in Brazil. Revista Do Instituto de Medicina Tropical de Sao Paulo, 61(Agustus 2020), 1-9. https://doi.org/10.1590/s16789946201961013

Nasrudin, Yusuf, A., Hargono, R., \& Suwandi, T. (2018). The Analysis of Influences of Family Stress Factors with ABCX Theory on Family with Leprosy in Jombang Regency , East Java , Indonesia. The 2nd Joint International Conferences, 29, 264270.

Retrieved

from

http://proceeding.tenjic.org/jic2/index.php/jic2/article/view/71/43.

Patmawati, Setiani N.O, (2015). Environment Risk Factors And Behaviors Of Leprosy Patients In Polewali Mandar Regency. Buletin penelitian kesehatan, 43:207-212.

Pribadi, T. (2016). Stigmatisasi penderita kusta di desa sidodadi asri banjar agung lampung selatan. Jurnal Kesehatan Holistik (The Journal of Holistic Healthcare), Volume 10, No.4.

Rahmawati, R., Nafiah, H., Koping, M., \& Kusta, P. (2015). Coping Mechanism of Leprae Patient. Jurnal Ilmiah Kesehatan (JIK), VII (I).

Ratnawati, R. (2016). Faktor-Faktor Yang Berhubungan Dengan Risiko Kejadian Morbus Hansen. Tunas Riset Kesehatan, VI(3), 103-109. Retrieved from : http://2trik.jurnalelektronik.com/index.php/2TRIK.

Sapriadi S, Risman Wanci, Syahridha. (2019) Hubungan Kebersihan Lingkungan dan Kelembapan Udara Dengan Kejadian Kusta di Kabupaten Jeneponto Retrieved from : http://journal.um-surabaya.ac.id /index.php/JKM. 


\section{STRADA Jurnal Ilmiah Kesehatan}

DOI: $10.30994 /$ sjik.v9i2.487

ISSN: 2252-3847 (print); 2614-350X (online)

Vol.9 No.2 November 2020 Page.1463-1473

Sermrittirong, S and Brakel, WHV. (2014). Stigma in Leprosy: concept, Causes and determinants. Journal Lepra Rev. Vol 85, p: 36 - 47

Sodik, M. A. (2016). Leprosy Patients in public perception: A qualitative study of patient confidence (dis) in the Community.

Sujan Babu Marahatta, Rakchya Amatya, Srijana Adhikari, Deena Giri, Sarina Lama, Nils Kaehler, Komal Raj Rijal, Suchana Marahatta, Bipin Adhikari. (2018). Perceived stigma of leprosy among community members and health care providers in Lalitpur district of Nepal: A qualitative study. https://doi.org/10.1371/journal.pone.0209676

Sutik Meru, Sri Winarsih, Tony Suharsono. (2017) Hubungan Tingkat Pengetahuan Tentang Kusta Dengan Kepatuhan Minum Mdt (Multidrug Therapy) Pada Pasien Kusta Di Puskesmas Kejayan Dan Puskesmas Pohjentrek Kabupaten Pasuruan, Vol 4, No 1, Maret 2017.

Syahrul, A. \&. (2019). Pengaruh Stigma Masyarakat terhadap Perilaku Pasien Kusta dalam Mencari Pengobatan: Sebuah Tinjauan Sistematis. 173-181. Received fom : https://doi.org/10.26699/jnk.v6i1.ART.p173-181

Tarigan, N. P. (2013). Serta Stigmatisasinya Di Indonesia. 4(45), 432-444.

Williams, A., Thomas, E. A., Bhatia, A., \& Samuel, C. J. (2019). Study of clinical spectrum and factors associated with disabilities in leprosy: A ten year retrospective analysis. Indian Journal of Leprosy, 91, 37-45.

Yadav, R., Khanna, A., \& Singh, D. (2017). Exploration of Relationship Between Stress and Spirituality Characteristics of Male and Female Engineering Students: A Comprehensive Study. Journal of Religion and Health, 56(2), 388-399. https://doi.org/10.1007/s10943-015-0174-7

Yusuf, A., Iswari, M. F., Nihayati, H. E., \& Okviasanti, F. (2016). Kebutuhan Spiritual Konsep Dan Aplikasi Dalam Keperawatan. Penerbit Mitra Wacana Media. https://doi.org/10.1002/nml.11308 